The University of San Francisco

USF Scholarship: a digital repository @ Gleeson Library |

Geschke Center

Economics, Law, and International Business

School of Management

1991

\title{
Legal Dimensions of Salespersons' Statements: A Review and Managerial Suggestions
}

\author{
Karl Boedecker \\ University of San Francisco, boedecker@usfca.edu \\ Fred W. Morgan \\ Jeffrey J. Stoltman
}

Follow this and additional works at: http://repository.usfca.edu/elib

Part of the Business Law, Public Responsibility, and Ethics Commons

\section{Recommended Citation}

Karl Boedecker, Fred Morgan, and Jeff Stoltman, "Legal Dimensions of Salespersons' Statements: A Review and Managerial Suggestions," Journal of Marketing, 55 (January), 70-80. 1991

This Article is brought to you for free and open access by the School of Management at USF Scholarship: a digital repository @ Gleeson Library | Geschke Center. It has been accepted for inclusion in Economics, Law, and International Business by an authorized administrator of USF Scholarship: a digital repository@Gleeson Library| Geschke Center. For more information, please contact repository@usfca.edu. 
Karl A. Boedecker, Fred W. Morgan, \& Jeffrey J. Stoltman

\section{Legal Dimensions of Salespersons' Statements: A Review and Managerial Suggestions}

Salespeople can generate liability problems for their organizations through both intentional and inadvertent statements, yet the sales management and personal selling literature has not provided adequate discussion of these problems. The authors describe the various ways salespeople initiate such liability and include specific advice for sales managers interested in guiding salesperson behavior.

A salesperson can consciously or inadvertently mislead prospects/customers at several stages during their interactions. Consider the enthusiastic salesperson who overstates the capabilities of a product, not realizing that his or her impassioned presentation contains impossible-to-meet promises. Such remarks could cause a dispute with the customer, maybe even resulting in litigation alleging that the apparently innocent statements amount to a warranty or product misrepresentation (Lenox v. Triangle Auto Alarm 1990).

The preceding scenario would be embarrassing and could result in an unprofitable transaction once the value of the unintended warranty is calculated. But what if the sales representative lies (Southern States v. Proctor 1989) or unfairly belittles competitors' products (Moore v. Boating Industry 1987)? Actions such as these can generate extremely negative publicity for the firm (Hoelterhoff 1989) and, depending on the consequences, can result in fines amounting to hundreds of millions of dollars (Business Week 1990a,b). Un-

Karl A. Boedecker is Professor, McLaren School of Business, University of San Francisco. Fred W. Morgan is Professor and Jeffrey J. Stoltman is Assistant Professor, School of Business Administration, Wayne State University. fortunately, scant advice for avoiding such situations is available in published materials.

As reflected in the literature, sales management usually stresses objective or productivity-related performance measures (Churchill et al. 1985), such as sales volume or calls, or other output measures (Churchill, Ford, and Walker 1990; Ingram and LaForge 1989). Most salesperson appraisal systems do likewise (Basu et al. 1985). In practical terms, pursuit of short-run objectives could jeopardize the longrun goal of most selling activity: establishing ongoing relationships with buyers (Dwyer, Schurr, and Oh 1987). This juxtaposition of goals can be manifested in several ways. For example, a salesperson "stretching the truth" in an effort to sell might alienate prospects and others who become aware of that behavior, yet would be rewarded if quotas are met.

A more comprehensive orientation to managing salespeople, whereby salesperson behavior is directed and controlled along several job-related dimensions, may simultaneously decrease liability exposure and increase the likelihood of developing profitable longterm relationships with customers (Anderson and Narus 1990). If sales managers were able to identify the appropriate actions and reactions of salespeople, their directives and control systems could be expected to help meet the broadly defined goals of customer and 
company needs satisfaction in an ethically responsible way. This approach to managerial control also draws managers' attention to the task of alleviating the problems created when legal dimensions of selling practices are either not sufficiently salient or not up-todate.

Anderson and Oliver (1987) conclude that most theoretical approaches to managerial control in general and to sales control in particular predict the use of behavioral controls under conditions of environmental uncertainty (e.g., unanticipated judicial opinions and pending legislation). In such situations the firm internalizes environmental risks by monitoring the activities of its salespeople. Successful activities can be emphasized and dangerous or risky behaviors can be discouraged and minimized.

Because of its dynamic and evolutionary nature, ${ }^{1}$ the legal environment is one in which behavioral controls for salespersons are especially fitting as currently allowable sales practices may not be tolerated in the future. For example, "sales talk" or "puffing," long a controversial part of the salesperson-prospect exchange, has been defined more precisely by the judiciary during the past few years (Jackson v. Krieger Ford 1989; Sack 1986a). The range of permissible exaggeration is gradually narrowing, thus making 1985's hyperbole an actionable warranty today.

Salespeople therefore must understand the basic legal implications of their activities and be required to behave in ways that do not undermine their firm's legal standing. The unique skills of each salesperson must be used to generate sales (an outcome focus); however, the salespeople must be cautioned and trained (a behavior focus) not to act in a way that precipitates unintended legal obligations.

The purpose of the following discussion is to provide an overview of these issues in marketing's legal environment. Examples of salesperson statements and activities that could lead to legal disputes are discussed. Guidelines for selling and sales management actions then are presented to enable the firm to mitigate embarrassing and financially damaging litigation arising from personal selling activities.

\section{Examples of Selling Practices That Can Lead to Liability ${ }^{2}$}

Most coverage of the legal environment of selling examines the relationship between salespersons and their

\footnotetext{
'The volatility of marketing's legal environment is well documented. Every issue of the Journal of Marketing includes a section titled "Legal Developments in Marketing" and the Marketing News regularly carries columns devoted to legal issues. For sales managers and salespersons, Sales \& Marketing Management provides legal updates and has featured several articles on law-selling topics (e.g., Sack $1985 a, b, 1986 a, b)$

${ }^{2}$ The sales practices described in these cases are meant to illustrate
}

firms. Such topics as hiring discrimination, expense account fraud, wrongful termination, and equal compensation are discussed relatively frequently (e.g., Manning v. Upjohn 1989; Sales \& Marketing Management 1988). The ways salespersons can create legal duties for the corporation through various statements, actions, or even inactions receive considerably less attention. The latter legal questions can be organized into five categories, as illustrated in Table 1.

\section{Creation of Unintended Warranties}

Sales representatives may inadvertently create warranties for their products by careless or inflated statements or conduct, improper use of promotional materials, showing samples, or even silence in the face of a customer inquiry. These warranties may be either express (Uniform Commercial Code 1972, \$2-313) or implied warranties of fitness for a particular use (Sack 1986b; Uniform Commercial Code 1972, §2-315; Vaccaro 1987).

A seller may create an express warranty orally, without intending to do so, and in fact without even using the term "warranty" (American Jurisprudence $1985, \S \S 88-90)$. For example, the use of printed promotional materials in discussions between a salesperson and a customer may amount to an affirmation of a fact or a promise of product performance. In one instance, an advertising brochure for a Ford truck showed pictures of the vehicle "off-road," crossing streams, ditches, and mountains. When the buyer had mechanical problems arising from similar use of the product, which the dealer's service department could not repair, Ford Motor Company was held liable for breach of an express warranty, even though Ford had not intended the pictures to be a warranty (Ford Motor v. Lemieux 1967; Grady 1983).

In a more recent case that confirms the earlier position taken by the courts, the manufacturer was found liable for breach of an express warranty when one of its products did not perform according to the standards stated by a sales representative (Lindemann v. Eli Lilly 1987). In Lindemann, an herbicide did not have the specific capabilities suggested by Eli Lilly's sales representative. Liability attached even though the salesperson's statements contradicted the promotional brochures. Similar outcomes have occurred in cases involving like circumstances (Clark Manufacturing v. Gold Bond Pharmaceutical 1987; Hayden v. Siemans Medical Center 1987).

Though courts sometimes allow latitude for "sales talk" or "puffing" in the form of oral representations, they apparently will not tolerate much overstatement when the seller happens to have more knowledge, ex-

the breadth of exposure salespeople create. These are examples, not prototypes, of improper practices. 
TABLE 1

An Overview of Salesperson Statements That Can Create Legal Obligations for the Firm

\begin{tabular}{|c|c|c|c|}
\hline Legal Issues" & Illustrative Cases & Salesperson Indiscretions & Consequences \\
\hline \multirow[t]{2}{*}{$\begin{array}{l}\text { Creation of } \\
\text { unintended } \\
\text { warranties }\end{array}$} & $\begin{array}{l}\text { Lindemann v. } \\
\text { Eli Lilly (1987) }\end{array}$ & $\begin{array}{l}\text { Salesperson inadvertently overstated } \\
\text { chemical product's technical } \\
\text { capabilities }\end{array}$ & $\begin{array}{l}\$ 6000 \text { (total price of product) } \\
\text { awarded to plaintiff }\end{array}$ \\
\hline & $\begin{array}{l}\text { Carpetland v. } \\
\text { Payne (1989) }\end{array}$ & $\begin{array}{l}\text { Salesperson promised a one-year } \\
\text { warranty for carpet, though sales } \\
\text { agreement expressly denied any } \\
\text { warranties }\end{array}$ & $\begin{array}{l}\$ 2388 \text { (total price of product) } \\
\text { awarded to plaintiff }\end{array}$ \\
\hline \multirow[t]{2}{*}{$\begin{array}{l}\text { Dilution of warning } \\
\text { effectiveness }\end{array}$} & $\begin{array}{l}\text { In re First } \\
\text { Commodity (1987) }\end{array}$ & $\begin{array}{l}\text { Salesperson told clients that } \\
\text { warnings in securities prospectus } \\
\text { were unimportant }\end{array}$ & $\begin{array}{l}\text { Plaintiffs certified for class } \\
\text { action litigation (prior cases } \\
\text { settled for } \$ 260,000 \text { to } \$ 3 \\
\text { million) }\end{array}$ \\
\hline & $\begin{array}{l}\text { Stevens v. Parke, } \\
\text { Davis (1973) }\end{array}$ & $\begin{array}{l}\text { Salespeople vigorously promoted } \\
\text { drug product without mentioning } \\
\text { warnings }\end{array}$ & $\begin{array}{l}\$ 400,000 \text { awarded to plaintiff } \\
\text { in wrongful death claim }\end{array}$ \\
\hline \multirow[t]{2}{*}{$\begin{array}{l}\text { Disparagement } \\
\text { of competitive } \\
\text { offerings }\end{array}$} & $\begin{array}{l}\text { Systems v. } \\
\text { Scientific (1976) }\end{array}$ & $\begin{array}{l}\text { Salespeople claimed that rival's } \\
\text { game tickets could be "read" without } \\
\text { tampering }\end{array}$ & $\begin{array}{l}\text { Defendant's sales staff } \\
\text { prohibited from making such } \\
\text { claims }\end{array}$ \\
\hline & $\begin{array}{l}\text { Testing v. } \\
\text { Magnaflux (1987) }\end{array}$ & $\begin{array}{l}\text { Salespeople made unverified } \\
\text { negative statements about rival's } \\
\text { chemical products }\end{array}$ & $\begin{array}{l}\text { Plaintiff's claims ruled } \\
\text { actionable-trial delayed until } \\
\text { proper forms filed with court }\end{array}$ \\
\hline \multirow[t]{2}{*}{$\begin{array}{l}\text { Misrepresentation of } \\
\text { own offerings }\end{array}$} & $\begin{array}{l}\text { Dunn v. Honeywell } \\
\text { (1982) }\end{array}$ & $\begin{array}{l}\text { Salesperson intentionally overstated } \\
\text { the capabilities of computer software }\end{array}$ & $\begin{array}{l}\$ 61,573 \text { actual }+\$ 30,768 \\
\text { punitive damages }+ \text { legal fees } \\
(\$ 24,628) \text { awarded to plaintiff }\end{array}$ \\
\hline & $\begin{array}{l}\text { Scott v. Mid } \\
\text { Carolina (1988) }\end{array}$ & $\begin{array}{l}\text { Salesperson lied to buyer about the } \\
\text { condition of a mobile home }\end{array}$ & $\begin{array}{l}\$ 3600 \text { actual }+\$ 6400 \text { punitive } \\
\text { damages awarded to plaintiff }\end{array}$ \\
\hline $\begin{array}{l}\text { Tortious } \\
\text { interference with } \\
\text { business } \\
\text { relationships }\end{array}$ & $\begin{array}{l}\text { Leigh v. Isom } \\
\text { (1982) }\end{array}$ & $\begin{array}{l}\text { Sales agent made false accusations } \\
\text { about franchisee before franchisee's } \\
\text { customers }\end{array}$ & $\begin{array}{l}\$ 65,000 \text { actual }+\$ 35,000 \\
\text { punitive damages awarded to } \\
\text { plaintiff }\end{array}$ \\
\hline
\end{tabular}

${ }^{a}$ These five categories are the legal causes of action where salesperson behavior has been a prominent factor. They are based on a 3/1/90 review of the Lexis (1985) legal database for all reported federal and state cases since 1940 involving salespeople. The search phrase included: "sales representative, salesperson, salesman, saleswoman, salespeople, sales agent, manufacturer's representative, and manufacturer's agent."

perience, or sophistication about the subject matter of the transaction (American Jurisprudence 1985, \$99). Thus, in an oft-cited case, the court found an express warranty in the statements of a used car salesperson that a car was "in A-1 shape" and "mechanically perfect" (Wat Henry Pontiac v. Bradley 1949). This outcome has been endorsed consistently in hundreds of automobile-related cases (e.g., Barksdale v. Van's Auto Sales 1989; Reilly v. Gene Ducote Volkswagen 1989). The practice of puffing has never been acceptable to most legal scholars, and courts have steadily narrowed its allowable boundaries (Preston 1975; Prosser and Keeton 1984).

The court in Sierra Diesel v. Burroughs (1987) confirmed this position. Here the plaintiff signed a contract for the delivery of computer equipment and associated software. The contract contained, among other language, a section stating that the contract was to serve as a final expression of the agreement between the parties, regardless of prior discussions or sales presentations. The contractual language essentially nullified the earlier representations of the defendant's salesperson, resulting in a lesser level of service performance. The plaintiff prevailed by showing that he had relied on the salesperson's statements and that the contracted level of service would not accomplish the tasks for which the data-processing system had been purchased. The salesperson's statements were deemed to be an express warranty, even though the signed contract stated otherwise.

Unmonitored sales practices also may lead to the unintended creation of an implied warranty of fitness for a particular purpose. This situation would occur (Uniform Commercial Code 1972, §2-315):

\footnotetext{
. . . where the seller at the time of contracting has reason to know any particular purpose for which the goods are required and that the buyer is relying on the seller's skill or judgment to select or furnish suitable goods, there is unless excluded or modified under the next section an implied warranty that the goods shall be fit for such purpose.
} 
Thus a sales representative creates an implied warranty when he or she knows or has reason to know of a specific use to which a buyer intends to put the product, and further knows or should know that the buyer is relying upon the salesperson's judgment about the appropriate product. For example, a buyer purchased a gas space-heater from Montgomery Ward and told the sales clerk of his intention to use it in a house trailer where he planned to raise chinchillas for breeding and pelting. The heater malfunctioned, resulting in the death of 330 animals. The salesperson's failure to inform the inexperienced buyer of the dangers associated with the intended use of the space heater amounted to the creation of an implied warranty of fitness for a particular purpose, the subsequent breach of which led to the recovery of $\$ 28,000$ in a product liability action (Frey v. Montgomery Ward 1977).

\section{Dilution of Warning Effectiveness}

A firm marketing a product that is likely to be dangerous when either used as intended or foreseeably misused, and knowing or having reason to know that the intended users may not realize the dangers involved, has a duty to provide reasonable warnings (Restatement 1979, §Torts, p. 388). Providing such a warning, however, may not adequately protect the marketer from liability if subsequent salesforce activity offsets its effect. Under some circumstances, vigorous personal selling efforts in support of the product may amount to "overpromotion," so diluting a marketer's warning that a court would find the manufacturer had failed to provide an adequate warning, thereby resulting in product liability exposure (Stevens v. Parke, Davis 1973; Swayze v. McNeil Laboratories 1987).

This doctrine has emerged through a series of cases involving prescription drugs (Incollingo v. Ewing 1971; Love v. Wolf 1964; Salmon v. Parke, Davis 1975; Stevens v. Parke, Davis 1973; Yarrow v. Sterling Drug 1969). Marketers of these products have a duty to warn the medical profession about any dangerous side-effects associated with the use of the product. Though the marketers had done so, evidence of "vigorous sales programs," including salesforce promotion of "wider use of the product than proper medical practice justified," resulted in jury verdicts for injured plaintiffs on the grounds that overpromotion had effectively negated the original warnings (Stevens v. Parke, Davis 1973). On appeal, the court further expressed its concern that ". . . numerous personal visits to physicians by salesmen, a highly effective means of promoting the use of chloromycetin, was not employed to disseminate information as to the drug's hazards, even though such warnings would have entailed no additional burden" (Stevens v. Parke, Davis 1973, p. 67). Thus, even where a marketer has met its duty to exercise reasonable care by providing warnings about product dangers, field sales representatives can effectively "water down" or otherwise offset the impact of those warnings (Cohen 1976). In these situations courts have suggested explicitly that juries, when determining defendant liability, weigh salespersons' underemphasis of warnings (Brochu v. Ortho Pharmaceutical 1981; Wooderson v. Ortho Pharmaceutical 1984).

Even more important, salespersons should not discourage clients or prospects from reading warnings. Securities salespersons in In re First Commodity (1987) explicitly stated to clients that certain legally mandated warnings were essentially unimportant and could be ignored. When the clients lost substantial sums of money because of rapidly declining securities prices, they successfully asserted that they would not have invested accordingly had they actually read the printed warnings in the offering prospectus. This conclusion is consistent with that reached in relation to the vitiating effect of promotional labels and informational package inserts on presumably effective print warnings (Morgan and Trombetta 1982).

\section{Disparagement of Competitive Offerings}

In the heat of competitive battle, a sales representative may make negative statements about a rival product. A certain degree of such conduct is tolerated, provided that it fits within the boundaries of general statements of comparison, with no specific assertions of unfavorable facts about the competitor's product (Prosser and Keeton 1984). Thus, a salesperson's negative statement about a competitor's product may lead to liability for the tort of disparagement, also referred to as trade libel or injurious falsehood.

Commercial evidence of libel can be traced back some 350 years to English cases (Dickes v. Fenne 1639). When a sales representative makes a false statement to a third person that is derogatory to a competitor's business and calculated to prevent others from doing business with the competitor, liability will arise where the false statement plays a material and substantial role in inducing others not to deal with the competitor, thereby leading to special damages in the form of lost trade or other dealings (Prosser and Keeton 1984, p. 976). Recent trends in the law, including the extension of First Amendment free speech protection to commercial speech, strongly suggest that an aggrieved business must show also that the statement was made with malice - that the defendant knowingly or recklessly perpetrated the false statement (Prosser and Keeton 1984, p. 136).

Another fundamental distinction that is just now evolving is the relationship between the party making the insulting statements and the party being disparaged. A firm has considerably greater protection against the disparaging comments of a competitor's salespersons than against similar statements made by a so- 
called "stranger," that is, a disinterested third party (Reinhard 1987, p. 748). One commentator has even suggested that verbal product comparisons made by salespersons may eventually be governed by principles similar to those constraining comparative advertising (Pompeo 1987).

A case involving two marketers of equipment, devices, and systems for testing commercial and industrial materials illustrates the distinction between nonactionable, generally unfavorable comparative statements and ones that may lead to liability for disparagement. In Testing Systems v. Magnaflux (1966), the plaintiff marketed a chemical product called Flaw Finder and the defendant sold a similar compound under the name of Spotcheck. The defendant's agents represented to the plaintiff's present and prospective customers that "the plaintiff's stuff is no good" and "the government is throwing them out." The defendant further made a false statement to the effect that the United States government had tested the plaintiff's product and found it to be only about $40 \%$ as effective as that of the defendant. The court held that general statements of product superiority, even when made in the form of an unfavorable comparison that exaggerates the quality of one's own product, are permissible. It also found, however, that (Testing Systems v. Magnaflux 1966, p. 289):

\begin{abstract}
there is a readily observable difference between saying that one's product is, in general, better than another's . . . and asserting that such other's is only $40 \%$ as effective as one's own. The former, arguably, merely expresses an opinion, the latter however, is an assertion of fact, not subject to the same frailties of proof, implying that the party making the statement is fortified with the substantive facts necessary to make it.
\end{abstract}

The facts in Systems Operations v. Scientific Games (1976) reveal a more subtle example of actionable disparagement. The litigants were both competing to supply lottery tickets for state lottery games. On several occasions the defendant's sales representatives suggested to prospective clients that the plaintiff's lottery tickets could be "broken," that is, read to determine whether they were winners without any visible signs of tampering. As a reuslt, the plaintiff had considerable difficulty contracting to supply lottery tickets. The defendant's salespersons could not effectively demonstrate how to "break" the plaintiff's lottery tickets during courtroom testimony. Hence, the rumors that its salespeople were spreading provided the basis for requiring the defendant to cease such disparagement.

There is some suggestion that comparisons generally unfavorable to a competitor's product are within the privileges of both competition for future business and puffing (i.e., permissible exaggeration). Modern courts appear to be losing patience with such defenses (Prosser and Keeton 1984, p. 975-6). In any event, it seems increasingly clear that a sales representative who either intentionally or recklessly makes a false statement about a competitor's product or business has taken a significant step toward creating legal liability for the tort of disparagement (Moore v. Boating Industry 1987; Sack 1985b).

\section{Misrepresentation of Own Offerings}

Sales personnel who make unsupported or distorted claims for their wares may create liability for misrepresentation, often referred to as fraud or deceit. Such liability can arise from deliberately misleading comments or statements of opinion that turn out to be unfounded.

Intentional misrepresentations consist of a false statement about a material fact, made with the intent that another party should rely on it, where that party does justifiably rely on the falsehood so as to suffer injury as a result (Restatement 1979, §525). A salesperson's intentional misstatement of an opinion may even give rise to an actionable fraud claim, where he or she has superior knowledge of the subject of a transaction so that the other party may reasonably regard it as a statement of fact. For example, a 51-yearold widow originally signed up for eight one-half-hour dance lessons at an Arthur Murray dance studio for $\$ 14.50$. By praising her minimal skills and potential, instructors induced her to contract for more than 2000 hours of dance lessons at a cost of more than $\$ 31,000$. A Florida appellate court held that the defendant's statements of opinion provided a sufficient basis for a fraud suit aimed at declaring the contract invalid (Vokes v. Arthur Murray 1968).

Scott v. Mid Carolina Homes (1987) provides another example of salesperson deception in which the plaintiff ultimately prevailed. Here, after reaching an agreement with a customer, a salesperson learned that he could sell the same mobile home to another prospect for almost twice its current price. The salesperson then contacted the original customer and told him that the trailer was damaged and that state law forbade the sale of a product in such condition. The customer even volunteered to sign a waiver to relieve the selling firm of liability for the damaged mobile home; however, the salesperson said that such a waiver was not allowable. Eventually the original buyer found out about the subterfuge and recovered on the basis of fraudulent deception on the part of the sales representative.

In addition to policing their sales personnel to prevent such deliberately misleading practices, sales managers must make their representatives cognizant that careless (negligent) or innocent misstatements about products may result in lawsuits (Restatement 1979, $\$ 522)$. This point is particularly important for industrial marketers whose products are expected to meet technical specifications and performance requirements for their customers. Suppliers of computer hardware 
and software have experienced an increased volume of litigation over the past decade from dissatisfied customers who claim that, though the supplier had no intent to deceive them, it nonetheless mistakenly made performance claims during the purchase negotiations that the product never fulfilled (Applications v. Hewlett Packard 1982; Walker 1982; Zammit 1982).

For example, in Dunn Appraisal v. Honeywell (1982), a sales representative declared that his computer software could execute several kinds of analyses when, in fact, it could not. The plaintiff, relying on the salesperson's advice, purchased the software, which failed to perform as the sales representative stated. The court found for the plaintiff, even though the salesperson apparently believed his presale claims to be true. Such "innocent representation" suits amount to a strict liability approach to misrepresentation, because the plaintiff need not prove either intentional or negligent misconduct, only justifiable reliance on the untrue statements (Clements Auto Supply v. Service Bureau 1971).

Liability also may attach even if the salesperson's false statements are not made directly to the person suffering the loss. In Joseph v. Norman LaPorte Realty (1987) a salesperson intentionally overstated the condition of a swimming pool to the buyer's agent, a pool inspection company. The buyer eventually recovered damages from the salesperson's employer on the basis of fraudulent misrepresentation.

These standards for misrepresentation are applied even more stringently in situations involving salespersons who are required by law to have certain expertise-for example, real estate salespeople (Fennell Realty v. Martin 1988; Wassell v. Colorado Real Estate Commission 1988)—or are "certified" through some accrediting mechanism. Industrywide efforts to elevate the qualifications of salespersons to a higher standard of professionalism have the dual impact of an expanded legal duty of performance and, it is hoped, increased customer confidence. Thus, carelessness or overstatement that constitutes puffing on the part of an automobile salesperson might, in fact, amount to a misrepresentation on the part of a securities salesperson (First National Monetary v. Weinberger 1987).

Innocent and negligent misrepresentation suits may become a particular problem for technical salespeople who often have extensive interaction with the prospect's employees before the sale. The risk of incurring liability on either of these bases could significantly inhibit the presale exchange of information.

\section{Tortious Interference With Business Relationships}

The key element in a tortious interference claim is the showing that the defendant's salespersons engaged in some form of "dirty tricks," that is, behavior considered to be unfair business practices (Sack 1985a).
Witkin $(1974$, p. 2643) describes tortious interference: "The wrong consists of intentional and improper methods of diverting and taking business from another which are not within the privilege of fair competition." Courts therefore must determine whether the scrutinized salesperson practices are genuinely unfair or merely legitimate "rough and tumble" methods for competing in the marketplace (Economation v. Automated Conveyor Systems 1988). To date, only very general guidelines for making this determination exist (Restatement 1979, §766B, comment c).

This approach to recovery has become popular in recent years because of plaintiffs' difficulty in proving that unacceptable salesperson behavior caused the loss of specific dollar amounts (contractual damages). This problem becomes acute when profits are nonexistent, cyclical, or unpredictably volatile. In addition, recoveries under contract law are not tied to the extent of the defendant's reprehensible behavior. An intentional breach of contract is treated like an inadvertent breach.

Recovery for tortious interference with economic relations, however, is based on the defendant's behavior and provides general or compensatory damages as well as potential punitive damages based on intent. Hence, blatant lies and concealment that lead to a breached contract can be penalized severely. For example, in Leigh Furniture v. Isom (1982), Leigh's agents harassed Isom, under contract to sell Leigh's furniture, for more than a year, making false accusations about his operating procedures in front of his customers. Isom eventually declared bankruptcy and sued Leigh for intentional interference with prospective economic relations. Isom recovered compensatory damages to cover his losses from the breach of contract by Leigh, as well as punitive damages.

The plaintiff in Mayes v. Sturdy Northern Sales (1979) recovered only general damages when the defendant failed to fulfill all terms of a contract to supply him with various products. The defendant decided to pay more attention to its house accounts and began to make late deliveries to its franchisees, including Mayes. Though these actions breached the contractual agreement, they were not sufficiently offensive to result in an award of exemplary damages.

Tortious interference also can occur without the existence of a contract. This situation normally involves salespersons from competitive companies vying for the same accounts (Shapiro 1983). For example, in the lottery case described before (Systems Operations v. Scientific Games 1976), the plaintiff also alleged tortious interference with prospective business advantage. Though the court found for the defendant on the disparagement claim, it could have used a tortious interference argument (Dowling 1986). The defendant had wrongly denigrated the plaintiff's lottery tickets to gain future business. 


\section{Implications and Discussion}

As the foregoing analysis suggests, salespersons can interact with prospects or customers in several ways that can lead to litigation. Exacerbating this problem is the tendency for plaintiffs to assert all possible causes of action for their lawsuits in the hope of convincing the court that at least one claim is valid. Conceivably, an aggrieved customer might use every legal theory mentioned herein when a salesperson behaves improperly.

A proactive managerial stance is needed to minimize the likelihood of legal proceedings and to bolster chances of successfully meeting a legal challenge grounded in salesperson behavior. A self-test of current supervisory and selling practices is a logical first step. The following guidelines are derived from the preceding complaints and decisions.

- Be sure all specific product claims (technical characteristics, useful life, performance capabilities) can be accomplished

- Be certain that all specific positive statements about offerings can be verified. In addition, any strong positive statement about offerings that cannot be demonstrated should be very general (e.g., "high quality" or "great value").

- Customers should be reminded to read warnings, particularly if they seem to be paying little attention to them. Never suggest to customers that warnings can be ignored or even taken lightly.

- Immediately caution customers who appear to be contemplating any improper product use. Cautionary statements should be very specific and related to each customer's product usage situation.

- Assess each customer's level of sophistication-the more inexperienced the customer, the greater the salesperson's legal obligations to deal cautiously with the customer.

- Be able to verify all negative statements about competitors' products, business conduct, and financial condition. Salespersons should try to avoid saying anything negative about competitors, particularly on topics that could be construed as rumors.

These admonitions may be self-evident or thought to be common business practices, yet they should be reviewed routinely by sales managers and salespeople. More specifically, sales managers must develop and follow programs to ensure that salespersons not only are aware of their legal responsibilities, but behave accordingly. Explicit recommendations for sales managers are offered in Table 2.

\section{Training Salespeople ${ }^{3}$}

Recent research on selling effectiveness leads to training suggestions for the development of both declara-

\footnotetext{
${ }^{3}$ There is little evidence that current sales training and retraining/ update programs incorporate adequate legal modules. Lists of salesperson training topics do not include legal materials (cf. Leigh 1987;
}

TABLE 2

Sales Management Programs Designed to Direct Salespeople to Comply With Legal Guidelines

1. Include detailed modules on legal guidelines in training schools for beginning salespersons. Training should focus on both declarative and procedural knowledge.

2. Routinely provide updated information to salespersons about the most recent judicial and statutory developments related to communications with prospects and customers.

3. Develop incentive compensation packages that encourage and reward salespersons for avoiding or forestalling litigious situations.

4. Review salesperson performance to identify quickly and decisively salespersons who engage in practices that might lead to legal problems.

5. Manage by example. Always follow the legal guidelines when accompanying salespersons in the field, and hold salespersons to the same standards when reviewing their performance.

tive and procedural salesperson knowledge. In reference to the former, effective salespeople are those who make fewer errors in categorizing prospects at successive stages of the sales process (Szymanski 1988, p. 74). In terms of legal risk, prospects will differ in some systematic way. Some prospects may interpret an overstatement about a product's performance as simply enthusiastic salesmanship. Other prospects may reasonably believe the statement, taking it as a promise of performance (warranty). Similarly, some buyers may realize that a disparaging remark about a competitor, stated humorously, is merely a joke. Others may take the comment out of context and accept it as true. Through brainstorming sessions, experienced salespeople and sales managers may be able to identify characteristics of prospects that differentiate them in terms of likelihood of reliance on spoken assertions.

Szymanski $(1988$, p. 75$)$ goes on to suggest that the pseudo-experience of role-playing helps trainees to formulate appropriate attribute information by relating it to their own behavior. If effective salespersons can assume and articulate various prospect roles such as those just described, sales trainees can observe the effects of their statements, perhaps even understanding how their comments could be misinterpreted. Sujan, Weitz, and Sujan (1988) and Leong, Busch, and Roedder John (1989) have emphasized the value of using expert salespersons in training, particularly through role-playing. Such a formal approach

Major 1990), nor do legal topics appear in scholarly research on sales training (Avlonitis and Boyle 1989; Futrell, Berry, and Bowers 1984; Russ et al. 1989). The authors' experiences with several Fortune 500 companies and smaller firms is that little attention is given to legal topics during sales training. 
to sales training provides some of the structure that inexperienced salespersons need (Kohli 1989).

In reference to procedural knowledge, the preceding recommendations are consistent with the findings of Leigh (1987), Leigh and McGraw (1989), and Leong, Busch, and Roedder John (1989) on the sales scripts used by experienced salespersons. The interactive scripts followed during initial and followup sales calls include considerable information exchange between prospect and salesperson, providing several opportunities for the salesperson to stray into areas of potential legal difficulty. One solution is to allow salespeople to develop their own rule codes for operationalizing selling scripts by having them observe or experience several typical selling situations (Leigh and McGraw 1989, p. 32). Again, role-playing could be very useful, providing the basis for rule code development.

It is imperative for training to build on salespersons' experiences, allowing them to generalize across customers or selling situations to devise consistently legal interactive scripts. Sujan, Sujan, and Bettman (1988) observed that effective salespersons varied their sales strategies less than ineffective salespersons, and concluded that deviation from given policies in response to situational factors leads to poor decisions. Clearly, sales policies on lawful behavior should be developed and applied in all contacts with customers and prospects.

These training suggestions raise a preeminent question: Does training produce a relatively permanent change in employee behavior? Latham (1988, p. 554), on the basis of a review of skills training in nonselling occupations, stresses the need for continual training and development efforts. Such efforts are particularly necessary when changes are occurring between what is currently required and what will be required for effective job performance. The evolutionary nature of selling's legal environment necessitates careful consideration of this issue.

Role-playing and other types of work group interaction are examples of informal controls that, according to Jaworski (1988, p. 28), are appropriate in settings characterized by uncertainty in the organization's macro environment. Given that the legality of many of the salesperson actions discussed here can depend on buyer characteristics and responses (a potentially fruitful future research topic), informal control mechanisms are particularly appropriate.

\section{Maintaining Training Advantages}

Corporate legal counsel must disseminate information about recent legal developments to sales managers, who must then communicate with salespersons. Because significant judicial decisions occur with no predictable regularity, changes in the legal environment must be communicated on an "as-occurs" basis. Sales training materials must be revised whenever a relevant court opinion is issued or statute is enacted. In addition, an occasional special communication may have to be distributed to each salesperson in response to legal developments.

These updates can be achieved easily with present communications technology such as interactive video, a highly regarded training tool (Russ et al. 1989). This approach enables each salesperson to pace his or her learning and to assess his or her knowledge level. Moreover, videos can easily be made current on a regular basis.

Periodic updates reinforce the impression that managers are serious about the legal aspects of selling activity, contributing to a responsible market-driven corporate culture. A programmatic effort to advise and update as a part of regular communications with the salesforce can provide salespeople the relevant information needed to enhance productivity and to manage themselves (Sujan, Weitz, and Sujan 1988).

Ingram and LaForge $(1989$, p. 392) note that, though legal guidelines often are subject to multiple interpretations, organizations usually issue straightforward guidelines on legal issues. The danger here is that such an approach oversimplifies the legal situation for salespersons, but a certain margin for error can be built into the guidelines if they are written conservatively. Specific rules are consistent with the use of behaviorally based salesforce control systems under conditions of environmental uncertainty (Anderson and Oliver 1987).

\section{Compensating Appropriate Salesperson Responses}

To guide salesperson behavior, sales managers should consider supplementing outcome-based incentives with behavior-based ones. Such an approach would focus inexperienced salespersons on the quality of their work, including understanding how their behavior can create legal obligations. This recommendation has been made by others for the development of sales representatives during their early career stages (Sujan, Weitz, and Sujan 1988, p. 16).

In a conceptual sense, this approach emphasizes the intrinsic reward orientation among salespersons, encouraging them to derive satisfaction from the performance of job tasks, not just from achieving quota. Weitz, Sujan, and Sujan (1986, p. 181) conclude that intrinsic reward orientation relates to salespersons' motivation to practice adaptive selling, regarded as the most effective approach to selling.

Unfortunately, intrinsic rewards, originating within the individual, cannot be dispensed by sales managers. As a compromise, incentives could be devel- 
oped to encourage salespeople to monitor their behavior for its legal consequences. For example, the typical precursor to a lawsuit is a customer complaint about the product, terms of sale, unfulfilled salesperson promises, or salesperson manners or attitude. Complaint categories could be developed by sales managers and each salesperson could be assigned a complaint "quota" per category. Some incentive compensation could be awarded for not exceeding the allowable number of complaints. Salespersons also could be praised or recognized informally by superiors (Ingram, Lee, and Skinner 1989).

The market structure may allow construction of quotas based on repeat business. Ongoing sales contracts, part of the definition of relational exchanges (Dwyer, Schurr, and Oh 1987), can be advantageous for both buyers and sellers. Perhaps a repeat-to-newbusiness ratio could be computed for each salesperson, with financial rewards bestowed for those with the highest values. This approach is advisable only if other incentives encourage the appropriate level of new account solicitation.

\section{Evaluating Salesperson Performance}

Performance appraisals provide opportunities for sales managers to consider salesperson behavior in addition to sales outcomes. Oliver and Swan (1989) found that buyers' perceptions of fairness are influenced positively by higher levels of seller input. If salespeople can provide such intangibles as timely information and post-sale service, customers will feel more fairly treated. By collecting customers' perceptions of salespersons' performance along these intangible dimensions, sales managers can provide behavior-based feedback to their subordinates (Muczyk and Gable 1987). Sales representatives might begin to understand why their behavior is hindering their achievements as assessed by traditional outcome measures, such as quota or sales volume levels.

Consistency in the evaluation of salespeople is also critical. Sales managers may be tempted to overlook inappropriate selling tactics employed by superior (according to objective measures) salespersons, particularly if no negative consequences result (Bellizzi and Hite 1989; Caywood and Laczniak 1986). Such a vague message could lead a salesperson to behave illegally if a substantial sales contract hangs in the balance.

\section{Leading by Example}

Sales managers therefore must set the example for salespeople to follow. The sales manager who urges subordinates to behave legally and ethically, yet who regularly overstates products' capabilities when accompanying salespersons, is sending an ambiguous message. Researchers have concluded that top managers' attitudes and ethical standards strongly influ- ence subordinates' perceptions and subsequent behavior (Carroll 1987). It follows that a similar relationship should be expected between sales manager deportment and salesperson behavior.

In addition, when salespeople make equivocal assertions about products or competitors to prospects or customers in the presence of sales managers, the managers must unfailingly remind the salespersons that such behavior is unacceptable. It can lead to legal consequences and can raise conflicts with other marketing programs (e.g., contradict promotional brochures). Any failure to correct such conduct could justifiably be taken as tacit approval of the action. The critical importance of the salespersons's immediate supervisor in setting the ethical tone for the salesforce has been suggested (Bragg 1987; Murphy and Dunn 1988) and must be heeded (Finn 1988).

Corporate policies, stipulated in codes of ethics, can provide another layer of guidance for salespeople and sales managers. By mandating legal and ethical conduct, organizations can create a culture that encourages and rewards scrupulous behavior (Burke 1990). Open recognition and discussion of ethical problems reinforces the importance of legal behavior and discourages risk-taking by salespeople. The organization must support sales mangers and find ways to provide the resources necessary for establishing, implementing, and controlling effective solutions to the salesforce liability problem.

\section{Conclusion}

Procedures for evaluating and minimizing the liability exposure emanating from salesperson behavior must begin with a review of the statements and actions of the salesforce. Because such a review will be highly circumstantial and difficult, the basic capabilities and instincts of the salesforce must be molded through appropriately conceived training, directing, compensation, and evaluation programs. Such programs serve the dual purposes of updating and refreshing salespersons' understanding of the legal environment and unambiguously directing selling efforts toward legal compliance and away from potentially damaging situations. Ultimately, managers must concretely support these activities and programs in both spirit and action and not allow them to degenerate into mere "consciousness raising" exercises.

Our discussion underscores the need for various assessments of current selling practices and encourages a proactive orientation toward legal issues on the part of sales managers and salespeople. Indirect evidence suggests that legal topics rarely receive formal attention in sales training programs (Kerr and Burzynski 1988); however, research is needed to assess the extent of this deficiency and the efficacy of current pro- 
grams. The issues raised here also provide a timely context for further research on the knowledge-based differences among salespeople, which seem to be central to the adaptive selling model (Weitz 1981).

\section{REFERENCES}

American Jurisprudence (1985). Rochester, NY: Lawyers CoOperative Publishing Co.

$\rightarrow$ Anderson, Erin and Richard L. Oliver (1987), "Perspectives on Behavior-Based Versus Outcome-Based Salesforce Control Systems," Journal of Marketing, 51 (October), 7688.

$\rightarrow$ Anderson, James C. and James A. Narus (1990), "A Model of Distributor Firm and Manufacturer Firm Working Partnerships," Journal of Marketing, 54 (January), 42-58.

Applications, Inc. v. Hewlett-Packard Co. (1982), 672 F. 2d 1076 (2d Cir.), 501 F. Supp. 129 (S.D. N.Y. 1980).

Avlonitis, George J. and Kevin A. Boyle (1989), "Linkages Between Sales Management Tools and Practices: Some Evidence From British Companies," Journal of the Academy of Marketing Science, 17 (Spring), 137-45.

Barksdale v. Van's Auto Sales, Inc. (1989), (Ohio App., April 27) (LEXIS, State library, Omni file), 38 Ohio St. 2d 127 (1988).

$\rightarrow$ Basu, Amiya K., Rajiv Lal, V. Srinivasan, and Richard Staelin (1985), "Sales Compensation Plans: An Agency Theoretic Perspective," Marketing Science, 4 (Fall), 267-92.

$\rightarrow$ Bellizzi, Joseph A. and Robert E. Hite (1989), "Supervising Unethical Salesforce Behavior," Journal of Marketing, 53 (April), 36-47.

Bragg, Arthur (1987), “Ethics in Selling, Honest!” Sales \& Marketing Management (May), 42-4.

Brochu v. Ortho Pharmaceutical Corp. (1981), 642 F. 2d 652 (1st Cir.).

Burke, James E. (1990), “Business Ethics," presentation, The Impacts of Marketing Decision-Making: A Workshop on Ethics in Marketing, Harvard Business School (May).

Business Week (1990a), "Putting the Fear of Crime Into Corporations" (March 12), 35.

(1990b), "Soon, Corporate Crime May Really Not Pay” (February 12), 35.

Carpetland U.S.A. v. Payne (1989), 536 N.E. 2d 306 (Ind. Ct. App.).

Carroll, Archie B. (1987), "In Search of the Moral Manager," Business Horizons, 32 (March/April), 7-15.

Caywood, Clark L. and Gene R. Laczniak (1986), "Ethics and Personal Selling: Death of a Salesman as an Ethical Primer," Journal of Personal Selling \& Sales Management, 6 (August), 81-8.

Churchill, Gilbert A., Jr., Neil M. Ford, and Orville C. Walker, Jr. (1990), Sales Force Management, 3rd ed. Homewood, IL: Richard D. Irwin, Inc.

Walker, Steven W. Hartley, and Orville C. Walker, Jr. (1985), “The Determinants of Salesperson Performance: A Meta-Analysis," Journal of Marketing Research, 22 (May), 103-18.

Clark Manufacturing Co. v. Gold Bond Pharmaceutical Corp. (1987), 669 F. Supp. 40 (D. R. I.).

Clements Auto Supply Co. v. Service Bureau Corp. (1971), 444 F. 2d 169 (8th Cir.).

Cohen, Marsha (1976), "Comment: Stevens v. Parke, Davis \& Co.," University of San Francisco Law Review, 10 (Spring), 683-95.

Dickes v. Fenne (1639), 82 English Reports 411.
Dowling, Donald C., Jr. (1986), “A Contract Theory for a Complex Tort: Limiting Interference With Contract Beyond the Unlawful Means Test," University of Miami Law Review, 40 (January), 487-518.

Dunn Appraisal v. Honeywell Information Systems, Inc. (1982), 687 F. 2d 877 (6th Cir.).

$\rightarrow$ Dwyer, F. Robert, Paul H. Schurr, and Sejo Oh (1987), “Developing Buyer-Seller Relationships,” Journal of Marketing, 51 (April), 11-27.

Economation, Inc. v. Automated Conveyor Systems, Inc. (1988), 694 F. Supp. 553 (S.D. Ind.).

Fennell Realty Co., Inc. v. Martin (1988), 529 So. 2d 1003 (Ala.).

Finn, William T. (1988), "How to Make the Sale and Remain Ethical," Sales \& Marketing Management (August), 8.

First National Monetary Co. v. Weinberger (1987), 819 F. 2d 1334 (6th Cir.).

Ford Motor Co. v. Lemieux (1967), 418 S.W. 2d 911 (Tex. Civ. App.).

Frey v. Montgomery Ward \& Co. (1977), 258 S.W. 2d 782 (Minn.).

Futrell, Charles M., Leonard L. Berry, and Michael R. Bowers (1984), "An Evaluation of Sales Training in the U.S. Banking Industry," Journal of Personal Selling \& Sales Management, 4 (November), 40-7.

Grady, Susan E. (1983), "Inadvertent Creation of Express Warranties: Caveats for Pictorial Product Representation," Uniform Commercial Code Law Journal, 15 (Winter), 26872.

Hayden v. Siemans Medical Center Co. (1987), 672 F. Supp. 724 (S.D. N.Y.).

Hoelterhoff, Manuela (1989), “At the GAF Trial, the Salesman Sings," Wall Street Journal (January 18), A14.

In re First Commodity Corp. of Boston (1987), 119 F.R.D. 301 (D. Mass.).

Incollingo v. Ewing (1971), 444 Pa. 263, 282 A.2d 206.

Ingram, Thomas N. and Raymond W. LaForge (1989), Sales Management: Analysis and Decision Making. Chicago: Dryden Press.

, Keun S. Lee, and Steven J. Skinner (1989), “An Empirical Assessment of Salesperson Motivation, Commitment, and Job Outcomes," Journal of Personal Selling \& Sales Management, 9 (Fall), 25-33.

Jackson v. Krieger Ford, Inc. (1989), (Ohio App., March 28) (LEXIS, State library, Omni file).

$\rightarrow$ Jaworski, Bernard J. (1988), “Toward a Theory of Marketing Control: Environmental Context, Control Types, and Consequences," Journal of Marketing, 52 (July), 23-39.

Joseph v. Norman LaPorte Realty (1987), 508 So. 2d 496 (Fla. Dist. Ct. App.).

Kerr, Meg and Bill Burzynski (1988), "Missing the Target: Sales Training in America," Training and Development Journal (July), 68-70.

$\rightarrow$ Kohli, Ajay K. (1989), "Effects of Supervisory Behavior: The Role of Individual Differences Among Salespeople," Journal of Marketing, 53 (October), 40-50.

Latham, Gary P. (1988), "Human Resource Training and Development," Annual Review of Psychology, 39, 545-82. 
Leigh Furniture and Carpet Co. v. Isom (1982), 657 P. 2d 293 (Utah).

Leigh, Thomas W. (1987), "Cognitive Selling Scripts and Sales Training," Journal of Personal Selling \& Sales Management, 7 (August), 39-48.

and Patrick F. McGraw (1989), "Mapping the Procedural Knowledge of Industrial Sales Personnel: A ScriptTheoretic Approach," Journal of Marketing, 53 (January), $16-34$.

Lenox, Inc. v. Triangle Auto Alarm (1990), No. 89-C-1743, slip op. (N.D. Ill., May 9).

Leong, Siew Meng, Paul S. Busch, and Deborah Roedder John (1989), "Knowledge Bases and Salesperson Effectiveness: A Script-Theoretic Analysis," Journal of Marketing Research, 26 (May), 164-78.

Lexis (1985), Learning Lexis. Dayton, OH: Mead Data Central.

Lindemann v. Eli Lilly \& Co. (1987), 816 F. 2d 199 (5th Cir.).

Love v. Wolf (1964), 226 Cal. App. 2d 378, 38 Cal. Rptr. 183.

Major, Michael J. (1990), "Sales Training Emphasizes Service and Quality," Marketing News (March 15), 5.

Manning v. Upjohn Co. (1989), 862 F. 2d 545 (5th Cir.).

Mayes v. Sturdy Northern Sales, Inc. (1979), 91 Cal. App. 3d 69.

Moore v. Boating Industry Associations (1987), 819 F. 2d 693 (7th Cir.).

Morgan, Fred W. and William L. Trombetta (1982), "Market Segmentation and Product Liability," Journal of Public Policy \& Marketing, 1, 15-24.

Muczyk, Jan P. and Myron Gable (1987), "Managing Sales Performance Through a Comprehensive Performance Appraisal System," Journal of Personal Selling \& Sales Management, 7 (May), 41-52.

Murphy, Patrick E. and Mark G. Dunn (1988), "Marketing Ethics: Empirical Views," paper presented at American Marketing Association Winter Educators' Conference.

$\rightarrow$ Oliver, Richard L. and John E. Swan (1989), "Consumer Perceptions of Interpersonal Equity and Satisfaction in Transactions: A Field Survey Approach," Journal of Marketing, 53 (April), 21-35.

Pompeo, Paul E. (1987), "To Tell the Truth: Comparative Advertising and Lanham Act Section 43(a)," Catholic University Law Review, 36 (Winter), 565-83.

Preston, Ivan L. (1975), The Great American Blow-Up: Puffing in Advertising and Selling. Madison, WI: University of Wisconsin Press.

Prosser, William L. and W. Page Keeton (1984), Torts, 5th ed. St. Paul, MN: West Publishing Co.

Reilly v. Gene Ducote Volkswagen, Inc. (1989), 549 So. 2d 428 (La. App.).

Reinhard, Rawn Howard (1987), "The Tort of Disparagement and the Developing First Amendment," Duke Law Journal (September), 727-59.

Restatement (Second) of Torts (1979), American Law Institute.

Russ, K. Randall, Joseph F. Hair, Robert C. Erffmeyer, and Debbie Easterling (1989), "Usage and Perceived Effectiveness of High-Tech Approaches to Training," Journal of Personal Selling \& Sales Management, 9 (Spring), 46-54.

Sales \& Marketing Management (1988), "New Job Protection for You?" (October), 69.

Sack, Steven M. (1985a), "The High Risk of Dirty Tricks," Sales \& Marketing Management (November 11), 56, 58-9.

(1985b), "Watch the Words," Sales \& Marketing Management (July 1), 56, 58. (1986a), "Legal Puffery: Truth or Consequences," Sales \& Marketing Management (October), 59-60.

(1986b), "Some Words on Warranties," Sales \& Marketing Management (December), 52, 54.

Salmon v. Parke, Davis \& Co. (1975), 520 F. 2d 1359 (4th Cir.).

Scott v. Mid Carolina Homes, Inc. (1987), 293 S.C. 191, 359 S.E. 2d 291 (S.C. App.).

Shapiro, Geri (1983), "The Prima Facie Tort Doctrine: Acknowledging the Need for Judicial Scrutiny of Malice," Boston University Law Review, 63 (November), 1101-49.

Sierra Diesel Injection Service, Inc. v. Burroughs Corp. (1987), 656 F. Supp. 426 (D. Nev.).

Southern States Ford, Inc. v. Proctor (1989), 541 So. 2d 1081 (Ala.).

Stevens v. Parke, Davis \& Co. (1973), 9 Cal. 3d 51, 507 P.2d 653, 107 Cal. Rptr. 45, 94 A.L.R.3d 1059.

Sujan, Harish, Barton A. Weitz, and Mita Sujan (1988), “Increasing Sales Productivity by Getting Salespeople to Work Smarter," Journal of Personal Selling \& Sales Management, 8 (August), 9-19.

- Mita Sujan, and James R. Bettman (1988), "Knowledge Structure Differences Between More Effective and Less Effective Salespeople," Journal of Marketing Research, 25 (February), 81-6.

Swayze v. McNeil Laboratories, Inc. (1987), 807 F.2d 464 (5th Cir.).

Systems Operations, Inc. v. Scientific Games Development Corp. (1976), 414 F.Supp. 750 (D. N.J.).

Szymanski, David M. (1988), "Determinants of Selling Effectiveness: The Importance of Declarative Knowledge to the Personal Selling Concept," Journal of Marketing, 52 (January), 65-77.

Testing Systems v. Magnaflux Corp. (1966), 251 F.Supp. 286 (E.D. Pa.).

Uniform Commercial Code (1972), American Law Institute and The National Conference of Commissioners on Uniform State Laws.

Vaccaro, Joseph P. (1987), “The Law and Selling,” Journal of Business \& Industrial Marketing, 2 (Winter), 45-50.

Vokes v. Arthur Murray, Inc. (1968), 212 S.2d 906, 28 A.L.R.3d 1405 (Fla. Dist. Ct. App.).

Walker, Craig M. (1982), "Computer Litigation and the Manufacturer's Defenses Against Fraud," Computer Law Journal, 3 (Spring), 427-55.

Wassell v. Colorado Real Estate Commission (1988), 773 P.2d 597 (Colo. App.).

Wat Henry Pontiac Co. v. Bradley (1949), 202 Ok. 82, 210 P.2d 348.

$\rightarrow$ Weitz, Barton A. (1981), "Effectiveness in Sales Interactions: A Contingency Framework," Journal of Marketing, 45 (Winter), 85-103.

$\rightarrow-$, Harish Sujan, and Mita Sujan (1986), “Knowledge, Motivation, and Adaptive Behavior: A Framework for Improving Selling Effectiveness," Journal of Marketing, 50 (October), 174-91.

Witkin, Bernie E. (1974), Summary of California Law, Torts, 8th ed., Vol. 4. San Francisco: Bancroft-Whitney.

Wooderson v. Ortho Pharmaceutical Corp. (1984), 325 Kan. 387, 681 P.2d 1038.

Yarrow v. Sterling Drug (1969), 408 F.2d 978 (8th Cir.), 263 F.Supp. 159 (D. S.D. 1967).

Zammit, Joseph R. (1982), "Computers, Software and the Law," American Bar Association Journal, 68 (August), 970-2. 